\title{
Bag om Det Gamle Testamente
}

Årets første nummer af Dansk Teologiske Tidsskrift byder på fire forskellige artikler. Den første har jeg selv skrevet. Den tager afsæt i den nyligt fratrådte lektor, dr.theol. Ole Davidsens arbejder om gaveteorier og udveksling. I en diskussion med hans fortolkning af Johannesevangeliet forsøger jeg at vise, at den grundlæggende struktur i evangeliet omhandler erkendelse og anerkendelse.

I anledning af 200-året for den svenske nyevangelikale leder Carl Olof Rosenius' fødsel (1816-1868) præsenterer Flemming KofodSvendsen hans liv og virke. Kofod-Svendsen gennemgår hans kirkelige og teologiske holdninger, som han ikke mindst fremsatte i bladet Pietisten. Rosenius var udpræget klassisk luthersk i sin teologi og loyal tilhænger af den svenske folkekirkeordning, mens vækkelseskredsene samtidig var udgangspunktet for hans virke.

Johannes Aakjær Steenbuchs artikel omhandler også et kirkehistorisk emne. Han undersøger grundtræk i de danske baptisters idehistorie. Steenbuch argumenterer for, at de danske baptister er kendetegenet ved en "narrativ personalisme", idet den personlige troshistorie, og ikke dogmatiske formuleringer, er centrale i den teologiske argumentation. Gennem analyser af centale baptistiske teologers tanker fra det 19. århundrede gennemføres denne pointe, der til slut føres frem til aktuelle udgivelser fra baptiske menigheder.

I den afsluttende artikel præsenterer Jesper Høgenhaven aktuel forskning om Kobberrullen (3Q15) fra Qumran. Ifølge Høgenhaven indeholder skriftet en litterær udgave af en skattejagt. Modtageren skal forestille sig at bevæge sig rundt i Det Hellige Land på jagt efter skatte fra Salomos tempel. Læseren opdager, at landets tilstand er miserabel, for skjulestederne viser sig at være ruiner og gravpladser. Samtidig giver selve instruksen om at fremdrage de skjulte tempelskatte håb om en lysere fremtid. Således svarer Kobberrullens budskab til Qumransamfundets kritiske syn på samtidens tempelkult og præsteskab. For dem lå landet metaforisk set i ruiner på det andet tempels tid, og de så frem til, at skattene fra det første tempel blev fundet frem igen.

Med håb om at læseren vil finde skatte i dette nummer af Dansk Teologiske Tidsskrift ønskes god læselyst. 